\title{
The Impact of Inflation on Financial Sector Development: Evidence from Nigeria
}

\author{
Afangideh U. J. ${ }^{1}$, Garbobiya T. S. ${ }^{1}$, Umar F. B. ${ }^{1} \&$ Usman N. ${ }^{1}$ \\ ${ }^{1}$ Monetary Policy Department, Central Bank of Nigeria, Nigeria \\ Correspondence: Usman N., Monetary Policy Department, Central Bank of Nigeria, Nigeria. E-mail: \\ Usmanstrategic@yahoo.com
}

Received: December 12, 2019

Accepted: January 26, 2020

Online Published: January 29, 2020

doi:10.5539/ijef.v12n2p56

URL: https://doi.org/10.5539/ijef.v12n2p56

\begin{abstract}
This paper examines the Impact of inflation on financial sector development in Nigeria using quarterly data from 2002-2017. Financial sector development is proxied using money supply as a share of GDP (M2/GDP).The AutoRegressive Distributive lag (ARDL) model is employed to carry out the estimation given the weakness of the Engle-Granger residual-based cointegration technique to test the long-run and short-run effects of the impacts of inflation on financial sector development. The results of the estimation reveal that there is a positive and statistically significant relationship between inflation and financial sector development in Nigeria. There is need to test for threshold effects of inflation on financial development in Nigeria.
\end{abstract}

JEL Classification: C32; E31; O16

Keywords: Inflation, Financial Sector Development, ARDL

\section{Introduction}

The stability of the financial sector is of great importance for economic growth and development of any economy, and the understanding of the macroeconomic determinants of financial sector stability would highly promote inclusive growth, Azariadis and Smith (1996) and Boyd et al. (2001). A well-developed financial sector tends to mobilize resources in a more efficient way and reallocate same to productive activities, to promote economic activities within the economy.

Inflation is a key macroeconomic variable that affects the stability of the financial sector and various measures are needed to control it in order to improve the performance of the financial sector, Boyd et al. (2001). Given the current emphasis on inflation targeting as a primary monetary policy framework by monetary authorities globally, the evaluation of the interrelationship between inflation and financial development becomes imperative. Inflation expectations are transmitted to the economy when individuals bargain for higher wages and firms in anticipation of the future rise in price adjust their prices accordingly Amato et al. (2002). It follows, therefore, to achieve overall economic stability and price stability requires a well-anchored inflation expectation.

The effects of public expectations on monetary policy rest on the credibility of the central bank's actions to tame future inflation expectations by pushing down current inflation Amato et al. (2002). When the effort of Central Bank to tame inflation is credible its ability to reshape inflation expectations would be enhanced.

Inflation affects the financial sector performance in many ways, among which are, it transfers funds from savers and investors to borrowers Bittencourt (2011). The implication is that the opportunity cost of holding currency in the future could discourage savings that have negative effect on bank performance. Investors would rather prefer to invest in non-inflationary capital projects to avoid losses inherent in declining purchasing power money, and these low savings will reduce the funds available at the disposal of banks. Another influence of inflation is the declining purchasing power of the currency overtimes, which affects the exchange rate regime of the central bank, worsening the trade performance of the economy and subsequently, have negative effect on the balance of payment and decline in the exchange rate.

In Nigeria, inflation has been proven to consistently affect the performance of the financial sector as expressed in the work of Oritoni (1981), who defined inflation as the creation of money that ultimately increases the prices of goods and reduces the purchasing power of the currency in question. If the decrease in the purchasing power is gradual as it was Nigeria's experience in the early 60 s, the condition would not be worrisome because no country 
is free of inflation. However, the only thing that makes the difference is the rate, and this can be measured using the annual rate of increase in the average price level. The aggregate financial sector performance in Nigeria is affected by high inflation and interest rate. However, the correlation between economic growth, inflation and interest rate and ultimately their effect on economic activities at the macroeconomic level are still subject to debate. In Nigeria, inflation has been contentious since the mid-1960s and has been a source of great concern. This is attributable to the fact that the variation in interest rate determines inflation rate, even as the nominal interest rate is the function of the real interest rate and Inflation expectations (Fisher, 1993). The historical relationship between the two shows that the higher the rate of inflation, the higher the rate of nominal interest rate establishing the close association between them and how they both affect economic activities at the macroeconomic level.

To determine real economic growth in Nigeria, with the objective of whether the rate of growth can sustain the increasing demand of the economy in the face of a growing population, this study aimed to examine the impact of inflation on the overall performance of the financial sector and how the outcome determines the lending decision of Nigeria banks.

\section{Litreature Review}

A growing number of literature has described how the persistent increase in inflation limits the ability of the financial sector to give out credit. Huybens and Smith (1998), Huybens and Smith (1999) stress the importance of information asymmetries in the credit market and show how persistent increase in inflation rate leads to credit market frictions with negative consequences for financial development in both the banking and equity market sectors. With this phenomenon, an increase in inflation rate reduces the return on money and assets. With this reduction in returns, it leads to credit market frictions. With this in place, it gives room for further increases in the inflation rate. This circular wheel makes the financial sector to grant fewer loans, leading to inefficiency in resource allocation and diminishing of intermediary activities that follow.

Some studies have also emphasized that the threshold for inflation plays a critical when informal frictions set it. Azariadis and Smith (1996) and Boyd et al. (2001) find that once the inflation rate is above the threshold level or high, credit market frictions will likely set in, which leads to a decline in financial sector performance and credit rationing. However, when inflation rate is low, credit market frictions will be negligible, and hence the level of inflation does not impede the flow of information and resource allocation.

Furthermore, Boyd and Smith (1998), Huybens and smith (1998), Huybens and smith (1999) suggest the existence of a third inflation threshold, where once the level of inflation exceeds the threshold of the upper level, perfect foresight dynamism does not allow the economy to converge at a steady-state equilibrium where there is a high level of activity in the financial system. Hence, when inflation reaches this level all the damage has been done. An additional increase in the level of inflation will have no consequence on financial sector development.

Another theoretical approach covered is through the returns on savings. Azariadis and smith (1996), Moore (1986), Choi et al. (1996) find that if the level of inflation is high, the returns on savings will be reduced. Given the reduction in return for savings, savings and savers will reduce with the number of borrowers being large and the existence of frictions. Credit becomes scarce. In addition, the role of political economy and institutions is stressed by Rajan and Zingales (2003) and Acemoglu et al. (2003). Rajan and Zingales (2003) argue that big political interests stifle competition which keeps the level of financial development low. However, Acemoglu et al. (2003) highlight the role of institutions. The study points out that countries that experience higher rates of inflation and poor macroeconomic performance are due to weak institutions used by the elites to suppress power to themselves.

On the empirical point of view, a few studies have examined the relationship between inflation and financial development. Boyd et al. (2001) examines the impact of inflation on financial market performance using crosscountry data on financial sector indicators and inflation. The paper finds a significant negative impact of inflation on financial development even when omitted variable bias is taken into account, and countries with high rates of inflation are excluded from the estimation. The study concludes by finding the relationship to be non-linear as the rate of inflation increases.

Similarly, BenNaceur and Ghazouani (2005) estimate the impact of inflation on financial sector development in the Middle East and North African (MENA) countries using a dynamic panel model and apply the Generalized Method of Moments (GMM) estimator. They find inflation to have negative effect on financial sector development but with no evidence of threshold levels after controlling for simultaneity and omitted variable bias, which might occur. Hence, they find that marginal increases in the level of inflation have a negligible effect on stock performance and banking sector development.

Khan et al. (2006) uses financial depth as a proxy for financial development. They constructed an econometric 
specification that takes into cognizance the threshold effect of inflation on financial development. They find that a rise in the level of inflation has a weak positive effect when the inflation rate is initially low and a negative effect occurs when there is a high inflation rate. On the threshold effects, the study found the threshold to lie between the ranges between 3-6\% depending on the measure/definition of financial sector development used.

Using a panel framework, Barnes (2001) investigated the relationship and threshold effect of the inflation-financial development nexus. The paper finds that when an interaction term between inflation and financial market development is used, the relationship becomes larger and more significant after the threshold level of inflation is reached.

The impact of inflation is felt heavily in developing countries. Keho (2009) uses an Auto-Regressive Distributed Lag (ARDL) model to examine the impact of inflation on financial development in seven countries (Benin, Burkina Faso, Cote D'Ivoire, Guinea-Bissau, Mali, Niger, and Senegal) in West Africa. The study concludes by finding no long-run relationship between inflation and financial development in six of the countries. In terms of causality, the study only found one country where inflation dampened financial development. In addition, Ozturk and Karagoz (2012) examine the impact of inflation on financial development in turkey using the ARDL methodology. They find long-run and short-run estimates of inflation to have negative impact on financial development. They also find that credit to private sector has an important role in contributing to decreasing the level of inflation.

Lee and Wong (2005) apply a Threshold Auto Regression (TAR) approach to study the relationship between inflation and financial development in Taiwan and Japan. They find one threshold inflation value for Taiwan and two for Japan. They conclude that changes in the inflation rate is one of several factors that cause structural changes in growth and financial sector development nexus.

Bittencourt (2011) investigated the role of inflation on financial development in Brazil using disaggregated data from 10 economically diverse regions in Brazil between 1985 to 2002. The time period covered inflation under multiple regimes. The study concludes by finding that inflation is detrimental to financial development, with the result being significant across all data sets and financial development measures.

In a panel study covering 44 African countries, Usman (2019) uses two definitions of financial sector development (share of broad money to GDP and share of Credit to the private sector to GDP) and finds that inflation is detrimental to financial development. This is also found when he uses an instrumental variable to control for endogeneity.

Abbey (2012) examines the impact of inflation on financial development in Ghana for over 20 years. The study used three dynamic econometric models: A bivariate Non-Linear Least Squares (NLLS), a bivariate ARDL and A bivariate Vector Autoregressive (VAR) models. From the findings, the results show that (I) there is no long-run relationship between inflation and financial development in Ghana (II) the study establishes threshold effects on the inflation-financial development nexus (11-16\%). Where below the threshold for inflation a small increase in inflation is accompanied by a minimal decrease in financial sector development.

Kim and Lin (2010) uses panel data of 87 countries over 47 years and employ Pesaran and Shin (1998) model to examine the inflation-financial development nexus. The study finds a negative relationship between inflation and financial sector development. However, they find a high rate of inflation boosts the financial market in the shortrun.

In conclusion, the theoretical literature points to a negative relationship between inflation and financial sector development. However, the empirical literature presents mixed findings.

\section{Data and Methodology}

\subsection{Data}

The data used in this study is quarterly time-series data from 2002Q1-2017Q4. The data were sourced from the Central Bank of Nigeria's statistics database

Empirical Model

$$
F D=\alpha+\beta_{1} \text { inf }+\beta_{2} G E+\beta_{3} \text { Trade }+\beta_{4} \text { Exchange rate }
$$

Where FD is financial development which can be defined as the ratio of Broad Money (M2/GDP) or CPS/GDP (Credit to private sector) as a share of GDP, inflation is captured by the consumer price index, GE is the government expenditure, trade is the sum of exports and imports as a share of GDP and exchange rate represents the Bureau De change rate for the Nigerian Naira over the review period. 


\subsection{Econometric Method}

We employ the Pesaran and Shin (1998) ARDL model. The error correction version of the ARDL model is stated as follows:

$$
\Delta y_{t}=\varphi+\sum_{i=1}^{k-1} \pi_{1} \Delta y_{t-i}+\sum_{i=0}^{k-1} \eta_{1} \Delta x_{t-i}+\lambda_{1} y_{t-k}+\lambda_{2} x_{t-k}+\varepsilon_{t}
$$

Equation (2) captures the error correction in the ARDL model in which, $\varphi$ is the constant vector parameter, $\pi$ and $\eta$ are the short-run parameters; $y_{t}$ captures the endogenous vector variable, $x_{t}$ is a vector of the other explanatory variables as outlined above and $\lambda_{1}$ and $\lambda_{2}$ are the parameters of the long-run relationship. $\varepsilon_{t}$ is error term, assumed to be serially uncorrelated and homoscedastic.

All the variables have to be stationary, either in level or at first difference, to check this property before proceeding to the full ARDL model, the study uses the Phillips and Perron (1988) unit-root test. This is to ensure that none of the variables is I(2); otherwise the use of the ARDL would be invalid.

\subsection{ARDL and Bounds Testing Procedure}

The Pesaran and Shin (1998) technique involve 2-stages. In the first stage, the existence of cointegration amongst the variables (bounds testing) is tested using the standard Wald or Fisher F-test using equation 2. The null hypothesis is that the coefficients of the lagged regressors in the error correction version of the ARDL model (equation 2) are zero i.e. $H_{0}: \lambda_{1}=\lambda_{2}=0$. This null is tested against the alternative hypothesis of $H_{1}: \delta_{1} \neq \delta_{2} \neq$ 0 . The second stage of estimation can only proceed once cointegration is established among the variables. At this stage, the short-run and long-run parameters are estimated (Note 1) using the following two equations:

Long-run equation:

$$
\hat{\lambda}_{1} y_{t}+\hat{\lambda}_{2} x_{t}=0 ; y_{t}=-\frac{\widehat{\lambda}_{2}}{\hat{\lambda}_{1}} x_{t}
$$

Obtained from a version of equation (3) where appropriate lags would have been selected for both the dependent and independent variables using any of the information criterion after confirming the existence of long-run relationships in Stage one.

Dynamic error correction equation for the short-run coefficients/parameters obtained from the equation below:

$$
\Delta y_{t}=a+\sum_{j=1}^{p} \alpha_{j} \Delta y_{t-j}+\sum_{j=0}^{q} \beta_{1 j} \Delta x_{t-j}+\phi e c m_{t-1}+v_{t}
$$

Where $e c m_{t-1}=y_{t-1}-\frac{\hat{\lambda}_{2}}{\hat{\lambda}_{1}} x_{t-1}$ obtained from (3) above; $y_{t}$ and $x_{t}$ are as previously defined; $\beta_{1 j}$ are the short-run parameters; $\phi$ measures the speed of adjustment to a new equilibrium whenever there is a shock. It also provides another means of validating the existence of cointegration or long-run relationship among the variables. It is expected to be negative and significant and less than one in absolute value for the model to be stable.

\subsection{Stability Checks}

A stability check is carried out on the model using Brown, et al. (1975) model of stability verification. The cumulative sum (CUSUM) and cumulative sum of square (CUSUMSQ) are called out on recursive regression residual. To accept that the model is stable, the plots must fall within $5 \%$ critical bounds of significance.

The CUSUM test is based on the cumulative sum of recursive residuals based on the first set of $\mathrm{n}$ observations. It is updated recursively and plotted against the breakpoints. If the CUSUM statistic stays within the $5 \%$ significance level, the estimated coefficients are said to be stable. A similar procedure is used to carry out the CUSUMSQ that is based on the square of recursive.

\section{Estimation and Results}

This section discusses the empirical results comprising of the preliminary results, unit root test, the bounds testing for cointegration, the long-run and short-run estimates of the model, and finally, the stability and diagnostics test results.

\subsection{Summary Statistics}

Table 1 below presents the summary statistics of the variables used in the estimation. All the series indicate a significant deviation from their mean values as shown by their standard deviation. Money Supply (M2) and trade are negatively skewed. The results also reveal that the data is not normally distributed as confirmed by the Jarquebera test which tests the goodness of fit of the data. 
Table 1. Summary statistics

\begin{tabular}{lccccc}
\hline & Money Supply (M2) & $\begin{array}{c}\text { Government } \\
\text { Expenditure(GE) }\end{array}$ & Exchange Rate & Inflation & TRADE \\
\hline Mean & 0.708324 & 0.065683 & 182.8158 & 115.0800 & 0.316791 \\
Median & 0.779952 & 0.061596 & 154.2200 & 103.5250 & 0.323917 \\
Maximum & 0.928390 & 0.143608 & 455.2600 & 246.3800 & 0.488858 \\
Minimum & 0.441727 & 0.038549 & 118.7000 & 41.70000 & 0.133956 \\
Std. Dev. & 0.145811 & 0.021206 & 82.61667 & 55.96210 & 0.077833 \\
Skewness & -0.51327 & 1.196350 & 2.076291 & 0.636237 & -0.19521 \\
Kurtosis & 1.740249 & 4.701628 & 6.127607 & 2.445016 & 2.325767 \\
Jarque-Bera & 7.041978 & 22.98814 & 72.06898 & 5.139187 & 1.618717 \\
Probability & 0.029570 & 0.000010 & 0.000000 & 0.076567 & 0.445143 \\
Sum & 45.33271 & 4.203730 & 11700.21 & 7365.120 & 20.27464 \\
Sum Sq. Dev. & 1.339436 & 0.028332 & 430007.4 & 197300.6 & 0.381657 \\
Observations & 64 & 64 & 64 & 64 & 64 \\
\hline
\end{tabular}

As earlier pointed out in chapter 3, the unit root properties of the data would be tested. We employ the phillpsPerron test.

Table 2. Unit Root Test

\begin{tabular}{lccc}
\hline Variable & Level & First Difference & Comment \\
\hline Inflation & 2.613138 & $-6.54376^{* * *}$ & $\mathrm{I}(1)$ \\
Government Expenditure & $-9.21306^{* * *}$ & $-33.78617^{* * *}$ & $\mathrm{I}(0)$ \\
Trade & $-3.80571^{* * *}$ & $-19.87982^{* * *}$ & $\mathrm{I}(0)$ \\
Exchange Rate & -1.29822 & $-4.384608^{* * *}$ & $\mathrm{I}(1)$ \\
M2 & -1.78789 & $-8.427976^{* * *}$ & $\mathrm{I}(1)$ \\
\hline
\end{tabular}

$*, * * \& * * *$ represent significance values at 1,5 and 10 per cent respectively.

Despite the ARDL modeling not requiring tests for unit root, The test is carried out to ascertain that no variable in the data in integrated of order I(2) or higher. This is because the ARDL procedure assumes that all variables are either I(0) or I(1). If a variable is found to be I(2), then the F-statistics are no longer valid, Pesaran et al. (2001).

Table 3. Bounds test

\begin{tabular}{lccrr}
\hline F-Bounds Test & \multicolumn{3}{c}{ Null Hypothesis: No levels relationship } \\
\hline Test Statistic & Value & Signif. & I $(0)$ & $\mathrm{I}(1)$ \\
\hline F-statistic & $\mathbf{3 . 9 4 4 5 8 7}$ & $10 \%$ & 2.2 & 3.09 \\
$\mathrm{k}$ & 4 & $5 \%$ & 2.56 & 3.49 \\
& & $2.5 \%$ & 2.88 & 3.87 \\
& & $1 \%$ & 3.29 & 4.37 \\
\hline
\end{tabular}

The ARDL model is executed in two phases. In phase 1, the existence of a long-run relationship is established using the bounds test approach. Table 3 above presents the bounds test results; the F-Statistic is greater than the upper and lower critical values at 5 and $10 \%$, respectively. We can, therefore, establish that there exists a long-run relationship between financial development and its determinants: inflation, trade, government expenditure and exchange rate in Nigeria.

Table 4. Long run model

\begin{tabular}{lcccc}
\hline Variable & Coefficient & Std. Error & t-Statistic & Prob. \\
\hline INFLATION & 0.004332 & 0.000569 & 7.612250 & 0.0000 \\
GE & 1.012302 & 1.097842 & 0.922083 & 0.3623 \\
TRADE & 0.767584 & 0.436563 & 1.758244 & 0.0868 \\
EXCHANGE RATE & -0.001478 & 0.000427 & -3.461356 & 0.0013 \\
C & 0.129852 & 0.215013 & 0.603929 & 0.5495 \\
\hline
\end{tabular}


Table 4 above presents the long-run ARDL model. There is a positive and statistically significant relationship between inflation and Financial Development as it is statistically significant at 1 per cent level. Hence, an increase in inflation leads to an increase in financial development. This is in agreement with English (1999), Aiyagari and Eckstein (1996) and Marom (1988), who present empirical evidence that inflation promotes financial development. However, the relationship between inflation and financial development is non-linear as English (1999) finds. Hence, there is a need to test for threshold effect of inflation on financial development. There is a caveat to this finding, as high inflation may not lead to a large expansion in the financial sector if currency substitution takes place in the economy.

Nonetheless, government expenditure \& trade are found to have a positive relationship with financial development. However, the findings are statistically insignificant. The exchange rate is negative and statistically significant at the $1 \%$ level.

\subsection{The Short-Run Model}

The model selected is ARDL $(8,0,0,3,2)$. Short-run coefficient estimates are shown in Table 5 . The error correction term carries a negative sign which is highly significant at the $1 \%$ level (Note 2) indicating that variables are cointegrated. The error-correction term indicates that about 35 per cent of the disequilibrium in financial development is corrected by short-run adjustment in each quarter. Hence,it is important to reduce the existing disequilibrium over time in order to maintain long-run equilibrium.

Table 5. Short-run model

\begin{tabular}{crrrr}
\hline & \multicolumn{3}{c}{ ECM Regression } & \\
\hline Variable & Coefficient & Std. Error & t-Statistic & Prob. \\
D(M2(-1)) & 0.177514 & 0.112276 & 1.581049 & 0.1222 \\
D(M2(-2)) & 0.077431 & 0.104974 & 0.737622 & 0.4653 \\
D(M2(-3)) & 0.137016 & 0.112840 & 1.214246 & 0.2321 \\
D(M2(-4)) & 0.394737 & 0.109817 & 3.594481 & 0.0009 \\
D(M2(-5)) & 0.326488 & 0.117093 & 2.788279 & 0.0082 \\
D(M2(-6)) & 0.248776 & 0.114693 & 2.169060 & 0.0364 \\
D(M2(-7)) & 0.456346 & 0.109829 & 4.155054 & 0.0002 \\
D(TRADE) & 0.458202 & 0.111836 & 4.097090 & 0.0002 \\
D(TRADE(-1)) & -0.275026 & 0.102417 & -2.685345 & 0.0107 \\
D(TRADE(-2)) & 0.391226 & 0.104644 & 3.738643 & 0.0006 \\
D(EXCHANGE_RATE) & $6.03 E-07$ & 0.000279 & 0.002157 & 0.9983 \\
D(EXCHANGE_RATE(-1)) & 0.001045 & 0.000322 & 3.249111 & 0.0024 \\
CointEq(-1)* & -0.353935 & 0.068392 & -5.175101 & 0.0000 \\
\hline
\end{tabular}

Table 6. Diagnostic tests

\begin{tabular}{ccc}
\hline Diagnostic Tests & & \\
\hline Test & F-Statistic & P-Value \\
\hline Serial Correlation & 0.54632 & 0.5838 \\
Hetroskedasticity & 0.48068 & 0.9467 \\
Mis-specification & 0.479178 & 0.4920 \\
\hline
\end{tabular}

Serial correlation test is carried out using LM test for serial correlation of variables, to test for functional form misspecification. Ramsey RESET test is used. Finally, heteroscedasticity is tested using white test.

We carry out a battery of tests to check for the stability of the model, from table 6 and figures $1 \& 2$. From table 6 , it can be observed that the model does not have serial correlation, Heteroskedasticy, and is correctly specified. Using Brown et al. (1975) stability tests, Figures 1 and 2 show that the plots for the CUSUM \& CUSUMSQ are stable within the $5 \%$ significance boundary. 


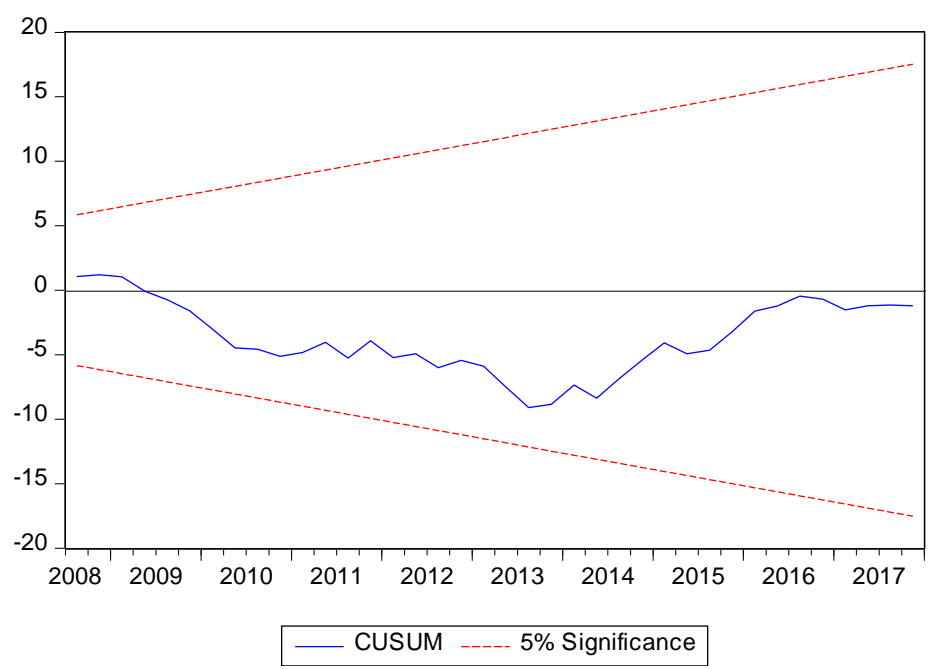

Figure 1. CUSUM

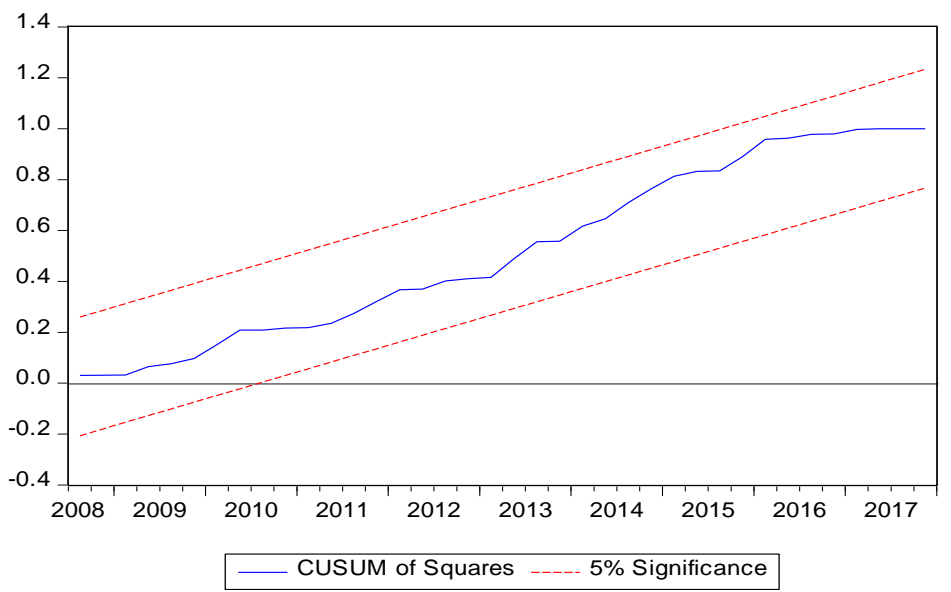

Figure 2. CUSUMSQ

\section{Conclusion}

This paper examines the impact of inflation on financial sector development in Nigeria using quarterly data from 2002-2017. Financial sector development is proxied using money supply as a share of GDP (M2/GDP). An AutoRegressive Distributive Lag (ARDL) model is employed to carry out the estimation given the weakness of the Engle-Granger residual-based cointegration technique to test the long-run and short-run effects of the impacts of inflation on financial sector development. The results of the estimation reveal that there is a positive and statistically significant relationship between inflation and financial sector development as it is statistically significant at the 1 per cent level in the long run. Hence, an increase in inflation leads to an increase in financial development. This is in agreement with English, (1999), Aiyagari and Eckstein (1996) and Marom (1988) who present empirical evidence that inflation promotes financial development. However, the relationship between inflation and financial development is non-linear as English (1999) finds. Hence, there is need to test for threshold effect of inflation on financial development. There is a caveat to this finding, as high inflation may not lead to a large expansion in the financial sector if currency substitution takes place in the economy.

\section{References}

Abbey, E. N. (2012). Inflation and Financial Development: Evidence. American Journal of Economics and Business Administration, 4(4), 227-236. https://doi.org/10.3844/ajebasp.2012.227.236

Acemoglu, D., Johnson, S., Robinson, J., \& Thaicharoen, Y. (2003). Institutional causes, macroeconomic symptoms: volatility, crises and growth. Journal of Monetary Economics, 50(1), 49-123. https://doi.org/10.1016/S0304-3932(02)00208-8 
Aiyagari, S. R., \& Eckstein, Z. (1996). Interpreting monetary stabilization in a growth model with credit goods production. Financial Factors in Economic Stabilization and Growth.

Amato, J. D., Morris, S., \& Shin, H. S. (2002). Communication and monetary policy. Oxford Review of Economic Policy, 18(4), 495-503. https://doi.org/10.1093/oxrep/18.4.495

Azariadis, C., \& Bruce, D. S. (1996). Private information, money, and growth: Indeterminacy, fluctuations, and the Mundell-Tobin effect. Journal of Economic Growth, 1(3), 309-332. https://doi.org/10.1007/BF00141041

Barnes, M. L. (2001). Threshold relationships among inflation, financial market development and growth. https://doi.org/10.2139/ssrn.842646

BenNaceur, S., \& Samir, G. (2005). Does inflation impact on financial sector performance in the MENA region? Review of Middle East Economics and Finance, 3(3), 219-229. https://doi.org/10.1080/14753680500407225

Bittencourt, M. (2011). Inflation and financial development: Evidence from Brazil. Economic Modelling, 28(1-2), 91-99. https://doi.org/10.1016/j.econmod.2010.09.021

Boyd, J. H., \& Bruce, D. S. (1998). The evolution of debt and equity markets in economic development. Economic Theory, 12(3), 519-560. https://doi.org/10.1007/s001990050234

Boyd, J. H., Ross, L., \& Bruce, D. S. (2001). The impact of inflation on financial sector performance. Journal of Monetary Economics, 47(2), 221-248. https://doi.org/10.1016/S0304-3932(01)00049-6

Choi, S., Bruce, D. S., \& John, H. B. (1996). Inflation, Financial Markets, and Capital Formation. Federal Reserve Bank of St. Louis Review, 78, 9-35. https://doi.org/10.20955/r.78.9-35

Dong-Hyeon, K., \& Shu-Chin, L. (2010). Dynamic relationship between inflation and financial development. Macroeconomic Dynamics, 14(3), 343-364. https://doi.org/10.1017/S1365100509090312

English, W. B. (1999). Inflation and financial sector size. Journal of Monetary Economics, 379-400. https://doi.org/10.1016/S0304-3932(99)00033-1

Huybens, E., \& Bruce, D. S. (1998). Financial market frictions, monetary policy, and capital accumulation in a small open economy. Journal of Economic Theory, 81(2), 353-400. https://doi.org/10.1006/jeth.1997.2372

Huybens, E., \& Bruce, D. S. (1999). Inflation, financial markets and long-run real activity. Journal of Monetary Economics, 43(2), 283-315. https://doi.org/10.1016/S0304-3932(98)00060-9

Keho, Y. (2009). Inflation and financial development: Cointegration and causality analysis for the UEMOA countries. International Research Journal of Finance and Economics, 27(10), 117-123.

Khan, M. S, Abdelhak, S. S., \& Bruce, D. S. (2006). Inflation and financial depth. Macroeconomic Dynamics, 10(2), 165-182. https://doi.org/10.1017/S1365100506050152

Lee, C., \& Swee-Yoong, W. (2005). Inflationary threshold effects in the relationship between financial development and economic growth: Evidence from Taiwan and Japan. Journal of Economic Development, $30(1), 49$.

Marom, A. (1988). Inflationand Israel's Banking Industry. Bank of Israel Economic Review, 30-41.

Moore, B. J. (1986). Inflation and financial deepening. Journal of Development Economics, 20(1), 125-133. https://doi.org/10.1016/0304-3878(86)90008-8

Ozturk, N., \& Kadir, K. (2012). Relationship between inflation and financial development: Evidence from Turkey. nternational Journal of Alanya Faculty of Business, 4(2), 81-87.

Pesaran, M. H., \& Yongcheol, S. (1998). An autoregressive distributed-lag modelling approach to cointegration analysis. Econometric Society Monographs, 31, 371-413. https://doi.org/10.1017/CCOL0521633230.011

Rajan, R. G., \& Luigi, Z. (2003). The great reversals: The politics of financial development in the twentieth century. Journal of Financial Economics, 69(1), 5-50. https://doi.org/10.1016/S0304-405X(03)00125-9

Usman, N. (2019). Growth of Financial Development In Sub Saharan African (SSA) Region Through Migrant Remittances. International Journal of Research -Granthaalayah, 7(3), 79-96.

\section{Notes}

Note 1. The lag length and lag criterion are chosen; the criterion could be any of Schwartz, Hannan Quinn or the Akaike. Stability and diagnostic checks are carried out for heteroscedasticity, serial correlation, functional form misspecification and normality of the data. 
Note 2. This reconfirms the cointegration amongst the variables in the model. The value lies between 0 and -1 where, a value of 1 indicates 100 per cent disequilibrium in the money demand function is corrected in the following quarter.

\section{Copyrights}

Copyright for this article is retained by the author(s), with first publication rights granted to the journal.

This is an open-access article distributed under the terms and conditions of the Creative Commons Attribution license (http://creativecommons.org/licenses/by/4.0/). 